\title{
ANALISIS CENDERAMATA KERAJINAN UKIR KAYU DI PASAR BUAH BERASTAGI DITINJAU DARI PRINSIP-PRINSIP DESAIN
}

\author{
Novriana Br Bangun $^{1 *}$, Brisman Silaban ${ }^{2 *}$ \\ Program Studi Pendidikan Seni Rupa, Jurusan Seni Rupa, Fakultas Bahasa dan Seni \\ Universitas Negeri Medan \\ Email : narukenovrianayahoo.com
}

\begin{abstract}
ABSTRAK
Penelitian ini bertujuan untuk mengetahui bagaimana peranan prinsip-prinsip desain pada cenderamata kerajinan ukir kayu yang dipasarkan di pasar buah Berastagi dan untuk mengetahui penyebab rendahnya minat beli wisatawan terhadap cenderamata kerajinan ukir kayu di pasar buah Berastagi. Penelitian ini dilakukan selama lima bulan sejak Februari sampai dengan Juni 2017 yang bertempat di pasar buah Berastagi. Metode penelitian yang digunakan adalah deskriptif kualitatif yakni data yang diolah berupa angka dan dijelaskan dengan cara deskriftif. Populasi dalam penelitian ini adalah sebanyak 30 cenderamata kerajinan ukir kayu dan ampel dalam penelitian ini adalah 15 cenderamata kerajinan ukir kayu yang dipasarkan di pasar buah Berastagi. Berdasarkan data yang telah dinalisis sesuai dengan tabel hasil penelitian maka hasil diketahui bahwa secara umum penerapan prinsip-prinsip desain pada cenderamata kerajinan ukir kayu di pasar buah Berastagi memiliki jumlah $=431,3$ dengan nilai rata-rata $=86,27$ dikategorikan baik. Prinsip desain A(kesatuan) memperoleh nilai rata-rata $=87$ (baik), prinsip desain $\mathrm{B}$ (keseimbangan) memperoleh nilai rata-rata $=85,6$ (baik), prinsip desain $\mathrm{C}$ (proporsi) dan prinsip desain $\mathrm{D}$ (harmoni) mendapatkan nilai rata-rata $=86,4$ (baik), prinsip desain $\mathrm{E}$ (irama) memperoleh nilai rata-rata $=85,9$ (baik).
\end{abstract}

Kata Kunci: cenderamata, kerajinan, ukir kayu

\section{PENDAHULUAN}

Sebuah objek wisata tidak akan pernah lengkap tanpa buah tangan atau cenderamata dari daerah itu sendiri. Karena cenderamata tersebut dapat dipergunakan dan ditujukan untuk banyak hal misalnya saja menjadi sarana promosi pengenalan suatu objek wisata, menjadi buah tangan wisatawan atau menjadi ajang kreasi dari pengerajin dan wirausaha pembuat cenderamata. Keberadaan cenderamata itu menjadi bukti keberadaan suatu budaya 
masyarakat suatu suku, dapat pula menjadi dokumentasi sejarah keberadaan dan perkembangan suatu budaya.

Wujud dari cenderamata itu sendiri tentunya memiliki ragam yang banyak mulai dari pakaian seperti baju, syal dan topi, aksesoris seperti kalung, gelang dang gantungan kunci, hiasan interior berupa pajangan dinding, meja maupun lemari serta penghias eksterior seperti lampu hias dan hiasan pintu. Tidak hanya sampai disitu produk cenderamata sendiri memiliki fungsi dan tujuan lain yang tidak kalah penting seperti untuk benda pakai lainnya misalnya untuk asbak, alat musik, kalender tradisional, tempat penyimpanan dan banyak fungsi lainnya.

Dilihat dari semua produk cenderamata yang berbeda dan fungsi masing-masing cenderamata yang paling menarik menurut peneliti adalah cenderamata berbahan dasar kayu, hal ini dikarenakan cenderamata kerajinan ukir kayu yang paling banyak dijual dan merupakan kerajinan yang berasal dari daerah karo pula. Dikarenakan hal tersebut penelitian ini akan berfokus pada cenderamata kerajinan ukir kayu yang dijual di pasar buah Berastagi.

Salah satu masalah yang paling besar yang ingin peneliti teliti adalah penyebab cenderamata terhusus kerajinan ukir kayu di pasar buah Berastagi kurang diminati pembeli. Alasan dibalik rendahnya minat wisatawan tehadapat cenderamata memiliki banyak penyebab. Apakah rendahnya minat beli wisatawan tersebut dikarenakan produk cenderamata tidak menerapkan prinsip-prinsip desain, apakah karena mematok harga yang terlalu tinggi, kualitas cenderamta yang kurang baik, ataukah cara pemasaran yang kurang efektif adalah pertanyaan yang ingin peneliti jawab dan ketahui.

Cenderamata yang baik tentu saja merupakan cenderamata yang menerapkan prinsip-prinsip desain dalam produknya. Tanpa menerapkan prinsipprinsip desain, sebuah cenderamata akan kurang menarik untuk dilihat juga tidak estetis dipandang mata. Tanpa menerapkan prinsip-prinsip desain ini produk cenderamata kurang laku dipasar. Hasil tinjauan lapangan yang peneliti lakukan juga menunjukkan bahwa penjualan cenderamata semakin menurun dari dari bulan ke bulan sepanjang tahun ini.

Melalui penelitian ini akan di ketahui apakah yang menjadi faktor rendahnya minat beli wisatawan terhadap cenderamata kerajinan ukir 
kayu di pasar buah Berastagi. Dengan melakukan penelitian ini diharapkan berdampak pada meningkatnya mutu serta kualitas dari cenderamata kerajinan ukir kayu yang dipasarkan di pasar buah Berastagi terutama dari penerapan prinsip-prinsip desain sehingga dapat meningkatkan daya jual pedagang cenderamata. Dengan melakukan penelitian ini pula diharapkan dapat menemukan solusi dari permasalahan penerapan prinsip desain dan penyebab rendahnya minat beli wisatawan. Penelitian ini sekaligus menjadi dokumentasi dan penambahan data tentang cenderamata yang terdapat di pasar buah Berastagi terhusus cenderamata kerajinan ukir kayu.

Sesuai dengan latar belakang masalah diatas maka identifikasi masalah dalam penelitian ini adalah penerapan prinsip-prinsip desain pada cenderamata kerajinan ukir kayu yang dipasarkan di pasar buah Berstagi, kualitas cenderamata kerajinan ukir kayu yang dipasarkan di pasar buah berastagi, jenis-jenis cenderamata kerajinan ukir kayu yang dipasarkan di pasar buah Berastagi dan penyebab rendahnya minat beli wisatawan terhadap cenderamata kerajinan ukir kayu di pasar buah Berastagi.
Penelitian ini akan dibatasi pada penerapan prinsip-prinsip desain pada cenderamata kerajinan ukir kayu yang dipasarkan di pasar buah Berastagi dan penyebab rendahnya minat beli wisatawan terhadap cenderamata kerajinan ukir kayu di pasar buah Berastagi.

Sesuai dengan rumusan masalah penelitian yang ditetapkan maka tujuan penelitian ini adalah Ingin mengetahui bagaimana peranan prinsip-prinsip desain pada cenderamata kerajinan ukir kayu yang dipasarkan di pasar buah Berastagi dan mengetahui penyebab rendahnya minat beli wisatawan terhadap cenderamata kerajinan ukir kayu di pasar buah Berastagi.

Manfaat dari penelitian ini antara lain:

1. Bagi penjual cenderamata menemukan penyebab rendahnya angka penjualan cenderamata kerajinan ukir kayu yang dipasarkan.

2. Bagi peneliti menjadi salah satu bentuk pengabdian karena lahir dan besar di Kabupaten Karo.

3. Bagi dunia pendidikan sebagai tambahan data dan dokumen tentang cenderamata karo khusunya yang terdapat di pasar buah Berastagi. 
4. Bagi pihak lain yang ingin melakukan penelitian sejenis menjadi sumber informasi pendukung dalam meneliti cenderamata kerajinan ukir kayu.

\section{KAJIAN PUSTAKA}

\section{A. Pengertian Analisis}

Menurut Sugiyono

$(2013: 335)$ analisis adalah proses mencari dan meyusun secara sistematis data yang diperoleh dari hasil wawancara, catatan lapangan, dan dokumentasi, dengan cara mengorganisasikan data ke dalam kategori, menjabarkan ke dalam unitunit, menyusun ke dalam pola, memilih maka yang penting dan yang akan dipelajari, dan membuat kesimpulan sehingga mudah dipahami oleh diri sendiri maupun orang lain.

\section{B. Pengertian Cenderamata}

Menurut pendapat (Hugh Wilkins, 2009:2) dalam jurnal Griffith University menyatakan The souvenir is an important component of the tourist experience with most tourists bringing back mementos and souvenirs as evidence. People like to be reminded of special moments in their lives and to hold evidence of those special moments, (cenderamata merupakan komponen yang penting dari pengalaman wisata dengan sebagian besar turis membawa kembali kenang-kenangan dan cenderamta sebagai bukti. Orang suka diingatkan akan momen spesial dalam hidup mereka dan untuk menahan bukti saat-saat khusus) .

Terdapat syarat-syarat dasar sebuah benda dikatakan cenderamata sebagai berikut:

1. Memiliki seni yang menonjol

2. Memiliki ciri khas daerah

3. Memiliki keunikan dan daya tarik

4. Kualitas dan mutu bahan yang baik

5. Harga relative terjangkau

6. Mudah dibawa

\section{Fungsi Cenderamata}

Dalam laman web repository.unika. ac.id/8734/2/06.30.0077\%20Sonny\%20A ndinata\%20BAB\% 20I.pdf, disebutkan bahwa cenderamata memiliki beberpa fungsi yaitu:

1. Cenderamata sebagai produk wisata dari suatu tempat tertentu.

2. Cenderamata sebagai hasil produk kerajinan.

3. Cenderamata sebagai pelengkap dan pemanis interior.

4. Sebagai barang fungsional.

5. Sebagai hasil seni budaya. 
6. Peningkatan pendapatan rakyat barang ukiran atau hiasan yang wilayah setempat.

7. Pemasukan devisa negara.

dihasilkan oleh seseorang yang dalam perwujudannya memerlukan

\section{Pengertian Kerajinan}

Menurut Sembiring (2014:127) Kerajinan merupakan cabang dari seni rupa terapan yang perwujudan hasilnya sangat memerlukan kekriayaan (craftsmanship) yang tinggi. Seni kerajinan juga sering dikaitkan dengan pekerjaan tangan (handicraft). Dalam bahasa Inggris, apa yang di Indonesia sering disebut kerajinan disebut "craft". Kata "craft" mengandung arti: keahlian, keterampilan khusus, seni, dan ketangkasan atau kecekatan. Lebih jauh kata "craft" juga berarti; keterampilan di dalam mengolah atau merencanakan dengan tangan; tipu muslihat; kelihaian. Juga diartikan sebagai pekerjaan atau kesibukan yang membutuhkan keahlian atau keterampilan khusus; khususnya beberapa seni-seni keterampilan tangan. Seni kerajinan atau kriya adalah seni yang dalam pembuatannya lebih memerlukan keterampilan tangan.

\section{E. Kerajinan Ukir Kayu}

Menurut Ferdinan Budi Saputro (2008:1) dalam Artikel Seni Ukir Indonesia menyebutkan pengertian kerajinan ukir kayu adalah barang-

keterampilan, ketekunan, dan perasaan seni dengan cara ditoreh, dipahat dan menggunakan tehnik ukir diatas media dari kayu.

\section{F. Jenis-Jenis Ukiran}

Menurut Bastomi (1982:3) terdapat enam jenis ukiran yang dihasilkan pengerajin seperti dibawah ini:

1. Jenis ukiran cembung

2. Jenis ukiran cekung

3. Jenis ukiran susun

4. Jenis ukiran garis

5. Jenis ukiran takokan

6. Jenis ukiran tembus

Sementara jenis ukiran dari tinggi rendahnya ukiran yang dihasilkan dapat dibagi menjadi enam jenis yakni:

1. Ukir rendah

2. Ukir sedang

3. Ukir tinggi

4. Ukir cekung

5. Ukir tembus

6. Ukir tumpang

\section{G. Peralatan Mengukir Kayu}

Adapun alat-alat yang digunakan dalam menciptakaan cenderamata kerajinan ukir kayu adalah sebagai berikut: 
1. Pahat ukir kayu yang terdiri dari: pahat penguku, pahat penyilat, pahat pengot, pahat kol dan pahat coret.

2. Palu ukir

3. Pisau ukir

4. Sikat ijuk

5. Batu asah

\section{H. Jenis-jenis Kayu}

Kayu adalah bahan utama yang dibutuhkan jika ingin membuat sebuah benda ukiran. Kayu untuk mengukir sendiri terdapat beragam jenis dengan kelebihan dan kekurangan masingmasing. Jenis kayu untuk karya krya kayu adalah sebagai berikut:

1. Kayu jati

2. Kayu mahoni

3. Kayu sonokeling

4. Kayu suren/burian

5. Kayu sungkai

6. Kayu bayur

7. Kayu pulai

\section{Sifat-sifat Fisik Kayu}

Menurut Enget,dkk dalam buku kriya kayu beberapa hal yang tergolong dalam sifat-sifat fisik kayu adalah berat jenis(BJ), keawetan alami, warna, higroskopik, tekstur, serat, berat, kekerasan, kesan raba, nilai dekoratif, dan beberapa sifat lainnya.

\section{J. Prinsip-prinsip Desain}

1. Defenisi Desain
Menurut Edward L.Mattil(1972:18), Designing is often considered that part of the creative process in which a fairly clear idea of the final art or craft producs is achieved and documented through sketches, samples, or models (Dalam mendesain sering dianggap bagian dari proses kreatif dimana idenya jelas mengenai suatu seni atau kerajinan yang mana produk ahirnya dicapai dan didokumentasikan melalui sketsa, sampel dan model)

2. Prinsip-prinsip Desain

Dalam Buku Wawasan Seni yang ditulis oleh tim dosen (2012:30) terdapat beberapa prinsip-prinsip desain yang dapat dijabarkan sebagai berikut:
a. Kesatuan((unity)
b. Keseimbangan(balance)
c. Proporsi
d. Harmoni atau keserasian
e. Irama

\section{K. Tentang Pasar Buah Berastagi}

Pasar buah berastagi mulai berdiri sejak tahun 1970 saat namanya masih menjadi pasar tarum tjuk (pasar atab ijuk). Nama itu diambil dari bentuk atap yang ada di pasar tersebut dimana pada saat itu dibuat dari bahan ijuk yang diikat dan dikumpulkan sehingga dapat menjadi atap dan melindungi orangorang yang ada di bawahnya. Sedangkan peresmian dari tempat ini dilakukan 
Pasar buah berastagi mulai berdiri sejak tahun 1970 saat namanya masih menjadi pasar tarum tjuk (pasar atab ijuk). Nama itu diambil dari bentuk atap yang ada di pasar tersebut dimana pada saat itu dibuat dari bahan ijuk yang diikat dan dikumpulkan sehingga dapat menjadi atap dan melindungi orang-orang yang ada di bawahnya. Sedangkan peresmian dari tempat ini dilakukan empat belas tahun setelahnya, yaitu pada tanggal 18 Mei 1984 oleh Bupati Karo pada saat itu Drs. Rukun Sembiring. Lokasi pasar tarum ijuk (pasar buah yang sekarang) pada saat itu berada di tempat pengisian bahan bakar minyak (SPBU) yang sekarang ini letaknya berada di samping pasar buah Berastagi.

empat belas tahun setelahnya, yaitu pada tanggal 18 Mei 1984 oleh Bupati Karo pada saat itu Drs. Rukun Sembiring. Lokasi pasar tarum ijuk (pasar buah yang sekarang) pada saat itu berada di tempat pengisian bahan bakar minyak (SPBU) yang sekarang ini letaknya berada di samping pasar buah Berastagi.

\section{METODE PENELITIAN}

\section{A. Lokasi dan Waktu Penelitian}

Penelitian ini berlokasi di Jl.Gundaling Tambak Lau Mulgap 1, Berstagi Kabupaten Karo. Waktu penelitian dilaksanakan sejak bulan Februari sampai dengan bulan Juni 2017.

\section{B. Populasi dan Sampel}

Populasi dlaam penelitian ini adalah sebanyak 30 buah cenderamata kerajinan ukir kayu yang dipasarkan di pasar buah Berastagi dengan 15 cenderamata dipilih sebagai sampel dimana mewakili bentuk maupun jenis yang sama.

\section{Instrumen Penelitian}

Dalam penelitian ini instrumen atau alat pengumpul data yang peneliti gunakan adalah catatan report, kamera, dan lembar Penilaian cenderamata.

\section{Metode Pengumpulan data}

Beberapa cara yang peneliti lakukan untuk memperoleh dan mengumpulkan data adalah wawancara, observasi, dan dokumentasi.

\section{E. Tehnik Analisis Data}

Tehnik analisis data yang digunakan dalam penelitian ini adalah tehnik analisi 
data deskriptif kualitatif dimana data yang diperoleh diuraikan dengan cara deskriptif dan data merupakan angka yang diperoleh dari Penilaian tim ahli terhadap cenderamata yang menjadi sampel.

\section{HASIL PENELITAN DAN \\ PEMBAHASAN}

\section{Kalender Tulang}

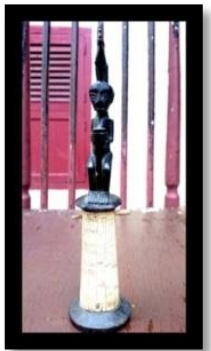

\section{Deskripsi Cenderamata :}

Terbuat dari kayu nangka dan tulang, berfungsi sebagai tempat obat (ingan tambar), pada bagian luar tulang tertulis kalender Karo dalam aksara Karo, dan alat ukir yang digunakan: pahat coret, penguku, penyilat, pisau ukir dan gergaji.

\section{Hasil Penilaian:}

1. Jumlah nilai rata-rata $=461,1$ dengan rata-rata $=92,2$ (sangat baik)

2. Rata-rata prinsip desain A (kesatuan) $=92,3$ (sangat baik)

3. Rata-rata prinsip desain $B$ (keseimbangan $)=91,6($ sangat baik $)$

4. Rata-rata prinsip desain $\mathrm{C}$ (proporsi) $=92,3$ ( sangat baik)

5. Rata-rata prinsip desain D (harmoni) $=93,6$ ( sangat baik)
6. Rata-rata prinsip desain $\mathrm{E}$ (irama) = 91,3 (sangat baik)

\section{Ingan Tambar}

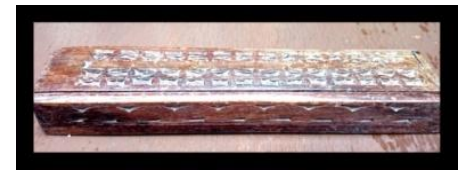

Deskripsi Cenderamata :

Ingan tambar (tempa tobat) terbuat dari kayu jati dan bagian dalam dilapis kain merah, digunkan sebagai tempat menyimpan obat terutama akar-akaran, dan menggunakan pahat penyilat, coret, penguku dan pisau ukir.

Hasil Penilaian:

1. Jumlah nilai rata-rata $=428,5$ dengan rata-rata $=85,7$ (baik)

2. Rata-rata prinsip desain A (kesatuan) $=87,3$ (baik)

3. Rata-rata prinsip desain B $($ keseimbangan $)=87,6($ baik $)$

4. Rata-rata prinsip desain $\mathrm{C}$ (proporsi) $=$ 86,3 (baik)

5. Rata-rata prinsip desain D (harmoni) $=85$ (baik)

6. Rata-rata prinsip desain E (irama)= 82,3 (baik)

\section{Miniatur Singa-singa}

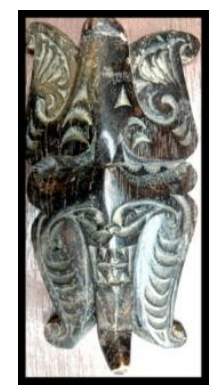


Deskripsi Cenderamata :

Merupakan adaptasi dari singa-singa yang terdapat pada Rumah Bolon, diyakini merupakan lambang dari wibawa, berfungsi sebagai hiasan dalam maupun luar rumah, memiliki banyak varian warna dan perubahan bentuk. Terbuat dari kayu ingul dan diukir dengan pahat penguku, coret, penyilat dan pisau ukir.

Hasil Penilaian:

1. Jumlah nilai rata-rata $=425,7$ dengan rata-rata $=85,1$ (baik)

2. Rata-rata prinsip desain A (kesatuan) $=86,6$ (baik)

3. Rata-rata prinsip desain $B$ (keseimbangan) $=84,6$ (baik)

4. Rata-rata prinsip desain $\mathrm{C}$ (proporsi) $=$ 85,6 (baik)

5. Rata-rata prinsip desain D (harmoni) $=84,6$ (baik)

6. Rata-rata prinsip desain $\mathrm{E}$ (irama)= 84,3 (baik)

\section{Cicak}

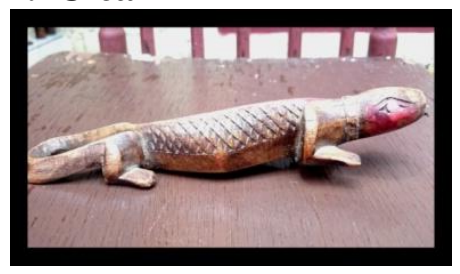

Deskripsi Cenderamata :

Merupakan pengembangan bentuk dari pengeret-ret yang terdapat di bagian luar rumah adat Karo, merupakan lambang kemakmuran, difungsikan sebagai hisan dinding dalam maupun luar rumah dan terbuat dari kayu mahoni dan diukir dengan pahat penguku, coret serta pisau ukir.

Hasil Penilaian:

1. Jumlah nilai rata-rata $=440,5$ dengan rata-rata $=88,1$ (baik)

2. Rata-rata prinsip desain A (kesatuan) $=87,6$ (baik)

3. Rata-rata prinsip desain B $($ keseimbangan $)=89,3$ (baik)

4. Rata-rata prinsip desain $\mathrm{C}$ (proporsi)= 89,3 (baik)

5. Rata-rata prinsip desain D (harmoni) $=87,3$ (baik)

6. Rata-rata prinsip desain E (irama)= 87 (baik)

\section{Bidak Catur}

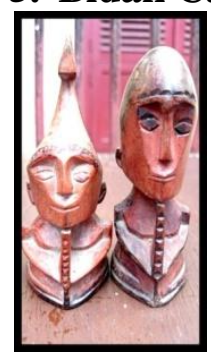

Deskripsi Cenderamata :

Merupakan pengembangan dari bentuk catur biasa dengan mengambil bentuk menyerupai patung duduk Karo, digunakan dalam permainan catur seperti biasanya. Tebuat dari kayu nangka dan diukir dengan pahat penguku, coret dan pisau ukir.

Hasil Penilaian:

1. Jumlah nilai rata-rata $=388,9$ dengan rata-rata $=77,8$ (cukup) 
2. Rata-rata prinsip desain A (kesatuan) $=81$ (baik)

3. Rata-rata prinsip desain B (keseimbangan) $=78$ (cukup)

4. Rata-rata prinsip desain $\mathrm{C}$ (proporsi) $=$ 75,3 (cukup)

5. Rata-rata prinsip desain D (harmoni) $=78$ (cukup)

6. Rata-rata prinsip desain $\mathrm{E}$ (irama)= 76,6 (cukup)

\section{Gantungan Kunci}

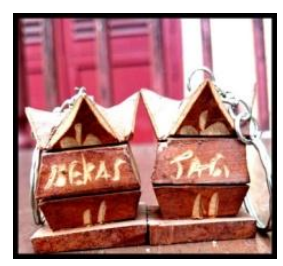

Deskripsi Cenderamata :

Merupakan penerapan bentuk menyerupai atap rumah adat Karo yang berbunyikan "BERASTAGI" yang menandakan asal cenderamata. Dimanfaatkan sebagai gantungan kunci biasa pada tas. Tebuat dari kayu nangka dan diukir dengan pahat coret, penyilat dan pisau ukir.

Hasil Penilaian:

1. Jumlah nilai rata-rata $=388,9$ dengan rata-rata $=77,8$ (cukup)

2. Rata-rata prinsip desain A (kesatuan) $=81$ (baik)

3. Rata-rata prinsip desain $B$ $($ keseimbangan $)=78($ cukup $)$

4. Rata-rata prinsip desain $\mathrm{C}$ (proporsi) $=$ 75,3 (cukup)

5. Rata-rata prinsip desain D (harmoni) $=78$ (cukup)

6. Rata-rata prinsip desain E (irama)= 76,6 (cukup)

\section{Miniatur Gapura Sidilaki}

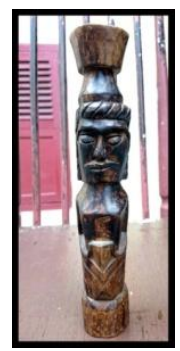

Deskripsi Cenderamata :

Merupakan pasangan dari Miniatur Gapura Sidiberu yang melambangkan kekuatan dan keperkasaan. Difungsikan sebagai hiasan ruangan dan terbuat dari kayu nangka dan diukir dengan pahat penguku, penyilat, coret, pisau ukir.

Hasil Penilaian:

1. Jumlah nilai $=423,5$ dengan rata-rata $=84,7$ (baik)

2. Rata-rata prinsip desain A (kesatuan) $=85,3$ (baik)

3. Rata-rata prinsip desain B (keseimbangan) $=80$ (baik)

4. Rata-rata prinsip desain $\mathrm{C}$ (proporsi)= 85,6 (baik)

5. Rata-rata prinsip desain D (harmoni) $=86$ (baik)

6. Rata-rata prinsip desain $\mathrm{E}$ (irama)= 86,6 (baik)

\section{Miniatur Gapura Sidiberu}

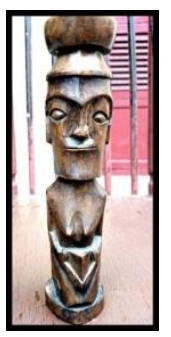

Deskripsi Cenderamata : 
Merupakan pasangan dari miniatur gapura Sidilaki yang melambangkan kesuburan dengan mengambil sosok wanita. Digunakan sebagai hiasan dalam rumah yang terbuat dari kayu nangka yang diukir dengan pahat penguku, penyilat, coret dan pisau ukir

Hasil Penilaian:

1. Jumlah nilai rata-rata $=435,2$ dengan rata-rata $=87$ (baik)

2. Rata-rata prinsip desain A (kesatuan) $=87,6$ (baik)

3. Rata-rata prinsip desain B $($ keseimbangan $)=85$ (baik)

4. Rata-rata prinsip desain $\mathrm{C}$ (proporsi) $=$ 86,3 (baik)

5. Rata-rata prinsip desain D (harmoni) $=88$ (baik)

6. Rata-rata prinsip desain $\mathrm{E}$ (irama)= 88,3 (baik)

\section{Singian Rumah}

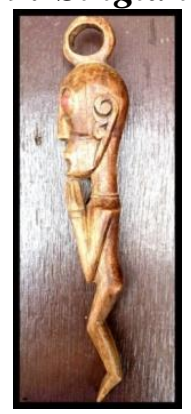

Deskripsi Cenderamata :

Mengambil bentuk patung duduk dengan bentuk badan segitiga terbalik.
Bagian kepala memiliki lubang tempat menaruh tali gantungan. Digunkan sebagai penjaga rumah Tebuat dari kayu nangka dan diukir dengan pahat penguku, coret, pisau ukir dan bor besi.

\section{Hasil Penilaian:}

1. Jumlah nilai rata-rata $=423,8$ dengan rata-rata $=84,78$ (baik)

2. Rata-rata prinsip desain A (kesatuan) $=87,3$ (baik)

3. Rata-rata prinsip desain $B$ (keseimbangan) $=81,6$ (baik)

4. Rata-rata prinsip desain $\mathrm{C}$ (proporsi)= 84 (baik)

5. Rata-rata prinsip desain D (harmoni) $=86,6$ (baik)

6. Rata-rata prinsip desain $\mathrm{E}$ (irama)= 84,3 (baik)

10. Miniatur Kecapi

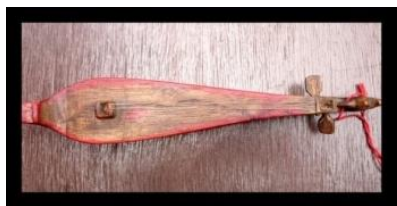

Deskripsi Cenderamata :

Mengambil bentuk asli kecapi Karo atau disebut kulcapi .Memiliki fungsi sebagai hiasan dinding atau meja. Terbuat dari kayu nangka dan diukir dengan pahat penyilat,penguku dan pisau ukir

Hasil Penilaian:

1. Jumlah nilai rata-rata $=439,1$ dengan rata-rata $=87,8$ (baik) 
2. Rata-rata prinsip desain A (kesatuan) $=87,3$ (baik)

3. Rata-rata prinsip desain B $($ keseimbangan $)=88,3($ baik $)$

4. Rata-rata prinsip desain $\mathrm{C}$ (proporsi) $=$ 89,3 (baik)

5. Rata-rata prinsip desain D (harmoni) $=88,6$ (baik)

6. Rata-rata prinsip desain $\mathrm{E}$ (irama)= 85,6 (baik)

\section{Miniatur Rumah Adat}

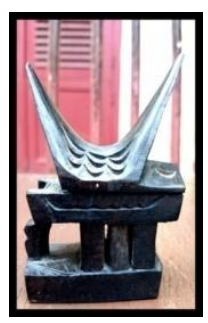

Deskripsi Cenderamata :

Mengambil bentuk sederhana dari Rumah Bolon. Berfungsi sebagai hisan pada meja maupun lemari hias.Terbuat dari kayu ingul dan diukir dengan pahat penyilat, coret, penguku dan pisau ukir.

Hasil Penilaian:

1. Jumlah nilai rata-rata $=439,1$ dengan rata-rata $=87,8$ (baik)

2. Rata-rata prinsip desain A (kesatuan) $=87,3$ (baik)

3. Rata-rata prinsip desain B $($ keseimbangan $)=88,3$ (baik)

4. Rata-rata prinsip desain $\mathrm{C}$ (proporsi) $=89,3$ (baik)

5. Rata-rata prinsip desain D (harmoni) $=88,6$ (baik)

6. Rata-rata prinsip desain $\mathrm{E}$ (irama)= 85,6 (baik)

12. Ukat Nakan

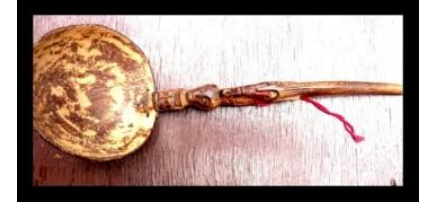

Deskripsi Cenderamata :

Ukat nakan(sendok nasi) tebuat dari kombinasi kayu nangka dan batok kelapa. Tangkai ukat nakan diberi patung duduk. Lebih difunsikan sebagai benda hias dari fungsi pakai. Diukir dengan pahat penguku, coret dan pisau ukir.

Hasil Penilaian:

1. Jumlah nilai rata-rata $=423,2$ dengan rata-rata $=84,6$ (baik)

2. Rata-rata prinsip desain A (kesatuan) $=87,6$ (baik)

3. Rata-rata prinsip desain B $($ keseimbangan $)=83,3$ (baik)

4. Rata-rata prinsip desain $\mathrm{C}$ (proporsi) $=$ 84 (baik)

5. Rata-rata prinsip desain D (harmoni) $=83$ (baik)

6. Rata-rata prinsip desain $\mathrm{E}$ (irama)= 85,3 (baik)

\section{Tanggalen Rumah Adat}

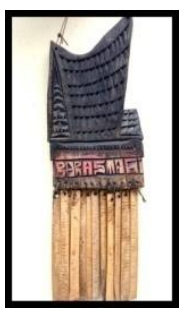

Deskripsi Cenderamata :

Merupakan kalender atau penanggalan yang menggunakan aksara 
Karo.Digunakan juga sebagai Hasil Penilaian:

pemercantik ruangan.Terbuat dari kayu nangka yang dikombinasi dengan bambu. Menggunakan alat ukir pahat penguku, penyilat, pengot, coret dan pisau ukir.

Hasil Penilaian:

1. Jumlah nilai rata-rata $=423,9$ dengan rata-rata $=84,4$ (baik)

2. Rata-rata prinsip desain A (kesatuan) $=84,3$ (baik)

3. Rata-rata prinsip desain B (keseimbangan) $=85$ (baik)

4. Rata-rata prinsip desain $\mathrm{C}$ (proporsi) $=$ 87 (baik)

5. Rata-rata prinsip desain D (harmoni) $=81,6$ (baik)

6. Rata-rata prinsip desain $\mathrm{E}$ (irama)= 86 (baik)

\section{Ikan Itik}

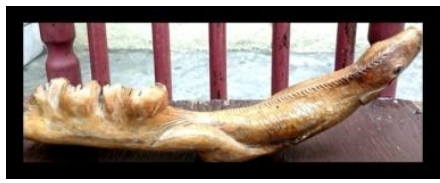

\section{Deskripsi Cenderamata :}

Mengambil bentuk ikan tawar yang disebut sebagai ikan itik. Difungsikan sebagai hiasan meja maupun lemari hias. Tebuat dari kayu jati dan diukir menggunakan pahat coret, penguku dan pisau ukir.

1. Jumlah nilai rata-rata $=434,8$ dengan rata-rata $=87$ (baik)

2. Rata-rata prinsip desain A (kesatuan) $=85,6$ (baik)

3. Rata-rata prinsip desain B (keseimbangan) $=87,6$ (baik)

4. Rata-rata prinsip desain $\mathrm{C}$ (proporsi)= 86,3 (baik)

5. Rata-rata prinsip desain D (harmoni) $=87,3$ (baik)

6. Rata-rata prinsip desain $\mathrm{E}$ (irama)= 88 (baik)

\section{Gantang Sira}

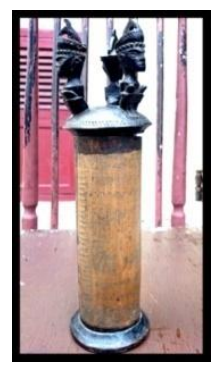

Deskripsi Cenderamata :

Gantang beras (mug beras) tutupnya dapat dipisah dengan tabung bambunya diaman bagian luar kulit 198amboo ditulis penanggalan Karo dengan aksara Karo dan tapak raja sulaiman. Dimanfaatkan sebagai penakar beras yang akan dimasak dan kadang sebagai tempat menyimpan garam. Dibuat dengan menggunakan alat ukit pahat coret, penyilat, penguku dan kergaji curva.

Hasil Penilaian: 
1. Jumlah nilai rata-rata $=456,8$ dengan rata-rata $=91,4$ (sangat baik)

2. Rata-rata prinsip desain $\mathrm{A}$ (kesatuan) $=$ 92,6(sangat baik)

3. Rata-rata prinsip desain $B$ $($ keseimbangan $)=90($ sangat baik $)$

4. Rata-rata prinsip desain $\mathrm{C}$ (proporsi)= 93,6 (sangat baik)

5. Rata-rata prinsip desain D (harmoni) $=92$ ( sangat baik)

6. Rata-rata prinsip desain E (irama)= 88,6 (baik)

\section{KESIMPULAN DAN SARAN}

\section{Kesimpulan}

Berdasarkan temuan penelitian pada bab terdahulu, maka penelitian ini dapat disimpulkan sebagai berikut:

1. Cenderamata yang dipasarkan di pasar buah Berastagi sudah menerapkan prinsip-prinsip desain dengan jumlah nilai $=1294,1$ dan dikategorikan baik. Cenderamata kerajinan ukir kayu kalender tulang memperoleh nilai ratarata=92,2(sangat baik), ingan tambar dengan nilai rata-rata $=85,7$ (baik), singa-singa dengan nilai ratarata $=85,1$ (baik), cicak dengan nilai rata-rata $=88,1$ (baik), bidak catur dengan nilai rata-rata $=91$ (sangat baik), gantungan kunci dengan nilai rata-rata $=77,8$ (baik), miniatur gapura sidilaki dengan nilai rata- rata $=84,7$ (baik), miniatur gapura sidiberu dengan nilai ratarata=87(baik), singian rumah dengan nilai rata-rata $=84,8$ (baik), miniatur kecapi dengan nilai ratarata $=87,8$ (baik), miniatur rumah adat dengan nilai rata-rata $=82,1$ (baik), ukat nakan dengan nilai ratarata $=84,6$ (baik), tanggalen rumah adat dengan nilai rata-rata $=84,8$ (baik), ikan itik dengan nilai ratarata=87(baik), dan gantang beras dengan nilai rata-rata $=91,4$ (sangat baik).

2. Penyebab rendahnya minat beli wisatawan terhadap cenderamata kerajinan ukir kayu di Berastagi adalah tingginya harga yang ditetapakan penjual terhadap cenderamata yang dipasarkan yang berakibat pada sedikitnya wisatawan yang mampu membeli.

\section{Saran}

1. Diperlukan adanya usaha promosi lebih untuk menonjolkan keberadaan cenderamata kerajinan ukir kayu yang terdapat di Pasar Buah Berastagi agar menarik miat wisatawan. 
2. Pengerajin cenderamata di pasar buah

Berastagi membutuhkan modal usaha dari dukungan pemerintah maupun swasta untuk dapat meningkatkan proses produksi cenderamta.

3. Para pengerajin kiranya membuat cenderamata dalam jumlah banyak sehingga cenderamata yang dijual memiliki harga yang terjangkau.

\section{DAFTAR RUJUKAN}

Admojo,Wahyu Tri, 2015, Keramik Tiga Karakter, Medan:Unimed Press

Arikunto, Suharsimi,2010, Prosedur Penelitian suatu Pendekaatn Praktik, Yogyakarta: Rineka Cipta

Bastomi, Suwaji,1986.Seni Ukir. IKIP Semarang. Semarang

Depdikbud, 2003, Kamus Besar Bahasa Indonesia, edisi ketiga, Jakarta :Balai Pustaka

Enget, dkk, 2008, Kriya Kayu Jilid 1, Jakarta: Direktorat Jenderal Manajemen Pendidikan Dasar dan Menengah.

Laporan Penelitian Pengumpulan dan Dokumentasi Ornamen Tradisional di Sumatra Utara.1977/1980. Pemerintah Daerah Tingkat I Provinsi Sumatra Utara.

Manurung,P. 2012, Metodologi Penelitian. Jakarta:Moeka

Martil, Edward L,1971,Menaing In Craft.Chairman,USA:Departement of Art Nort Texas State University.
Rais, Sigit,2009.Jadi Jutawan Dari Hobi, Yogyakarta: Indonesia Tera

Sachari, Agus. 1986, Paradigma Desain Indonesia Pengantar dan Kritik, Jakarta: Rajawali.

Saiman Rais dan Suhirman. 2000. Penuntun Belajar Mengukir Kayu Bagi Pemula :Adicita Karya Nusa

Sugito, dkk, 2015, Metode Pendidikan Seni Rupa, Medan,Unimed Press

Sugiyono, 2013, Metode Penelitian Pendidikan, Bandung:Alfabeta.

Tim Dosen, 2012, Wawasan Seni, Medan: Unimed Press.

Said, 1992, dalam e-jornal http://www.google.com/frepository.unik a.ac.id.

Condro Wiratmoko dkk,Jurnal Pendidikan Seni Rupa, Volume 2 Nomor 3 Tahun 2014, Suwardi : Tokoh Pengembang Wayang Beber di Pacitan.Universitas Negeri Semarang.

Putu Eka Juniarta dkk, e-Journal Universitas Pendidikan Ganesha Jurusan Pendidikan Seni Rupa Volume X Tahun 2013, Seni Kerajinan Tempurung Kelapa di Desa Tampaksiring,Kecamatan Tampaksiring, Kabupaten Gianyar. Universitas Pendidikan Ganesha Singaraja, Indonesia.

Dahliani, Jurnal Info Tehnik Volume 9 No.1, Juli 2008 (82-08):Studi Penerapan Prinsip-prinsip Desain Pada Masjid Noor Banjarmasin.Unlam Banjarmasin. 
Wilkins Hugh, Souvenir: What and Why we buy. 2009. Griffin University, Queensland, Australia.

Artikel

Mesra

Pdf,http://digilib.unimed.ac.id/id/eprint/4 28.

Saputro, Ferdian Budi, 2008, Artikel Seni Ukir Indonesia dalam laman https://id.scribd.com/doc/2489951 0/artikel-seni-ukir

Dahliani, Studi Penerapan PrinsipPrinsip Desain Pada Masjid Noor Banjarmasin Jurnal Info Tehnik, Volume 9 No.1 Juli 2008.

http://blogsenirupa.blogspot.co.id/2013/09/je nis-jenis-kayu-untuk-karya-kriyakayu.html (Diakses tanggal 04 Oktober pukul 13.05).

http://www.slideshare.net/maurit_simanj untak/kriya-kayu-jilid-1-smk-x (Diakses tanggal 01 Oktober pukul 10.23).

https://id.wikipedia.org/wiki/Cendera_m ata (Diakses tanggal 14 November pukul 16.00).

https://id.wikipedia.org/wiki/Ukiran (Diakses tanggal 20 November pukul 11.25.

http://www.lepank.com/2012/07/pengert ian-analisis-menurutbeberapa.html (Diakses tanggal 3 Desember pukul 14.32.

http://kemenpar.go.id/asp/index.asp (Diakses tanggal 3 Desember pukul 14.02.

http://www.karokab.go.id/id/index.php/p otensidaerah/pariwisata /tujuan- wisata/pajakbuahberastagi Diakses tanggal 24 Januari pukul 10.05).

http://www.guru pendidikan.com/13pengertian-analisis-menurut-paraahli-didunia/ (Diakses tanggal 10 Februari pukul 15.07). 